\title{
小麦たんぱく(グルテン)を配合した 奨油の味と色
}

油の原料は大豆と小麦は良く知られているが小麦たんぱくの使用はあまり知られていない。小麦たんぱ くの利用は錗菌の酵素作用により旨味が増強され, さらに褐変反応抑制効果が期待できるという。光れらの メカニズムを詳しく解説していただいた。

\section{岡 田 崇・桂 晴 美・古林 万木夫}

\section{1.はじめに}

小麦たんぱく（グルテン）は小麦粉に水を加えて混 捏した生地（ドウ）から，塩水によって糖質や水溶性 タンパク質を洗い落とした後に残る粘弾性に富む塊を いう1。小麦たんぱくは小麦中に約 10\%含まれ，その 構成アミノ酸の約 $40 \%$ がグルタミン（Gln）である。 Gln は，酱油醸造中に耧菌の生産するグルタミナーゼ により旨味成分であるグルタミン酸（Glu）に変換さ れるため, 小麦たんぱくを小麦の副原料として用いた 輏油はGluを多く含むことが期待される。しかしな がら, 酱油醸造中に Gluや Gln 一一部が, 非呈味性 のピログルタミン酸 (pGlu) に化学的に変換されて しまうことが知られている。一方，最近のぺプチド研 究では, 小麦たんぱくの酵素分解物から様々な機能性 ペプチドが単離されており ${ }^{2,3)}$, 遊離の Gluや Gln と 同様に, $\mathrm{N}$ 末端の Glu や Gln が化学的変換を受けて ピロ化されたピログルタミン酸ペプチド（pGluペプ チド）に呈味増強効果があることが報告されている4)。

また，小麦たんぱくの酵素分解物からは，抗酸化作 用をもつペプチドも単離されている。酱油の褐変着色 物質であるメラノイジンを生成させるアミノカルボニ ル反応は，温度の上昇や酸素の存在で著しく促進され るが, 特に酸化条件下で進行する褐変は, 使用中の色 の濃化などの品質劣化をもたらす主な要因である。そ れゆえ, 酱油中に存在する抗酸化ぺプチドは, 酱油の
抗酸化力を高めることで酱油の褐変抑制に寄与してい る可能性が考えられた。

本稿では, 特に呈味の増強や褐変抑制の観点から酱 油原料に小麦たんぱくを配合することの意義について 述べる。実験方法など詳細については, 原著論文を参

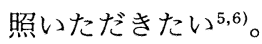

\section{2. 置油中の pGlu ペプチドと呈味性}

長期にわたる滰油醸造では，遊離アミノ酸である Glu や Glnの一部がピロ化されるが3), ペプチドにお いても $\mathrm{N}$ 末端でピロ化が進行することが予想され, 呈味増強効果の高い pGlu ペプチドは, 特に小麦たん ぱくを副原料に用いた酱油の呈味性に大きく寄与して いることが推察された。pGluペプチドの定量は, 酱 油試料を pyroglutamate aminopeptidase で処理する ことにより， $\mathrm{N}$ 末端の pGlu を切除し，酵素処理前と 処理後の遊離 pGlu 量の差から算出することができる (以下，ペプチド結合型 pGlu ${ }^{7-9)}$ 。そこで，小麦たん ぱくを副原料（原材料重の 0-20\%）として用いた試 醸奨油（以下，小麦たんぱく配合酱油）について， Glu や遊離 pGlu, ペプチド結合型 pGlu について成分 特性を明らかにするとともに，調理試験を実施して酱 油の呈味性に関する検討を行った6)。

小麦たんぱく配合量に依存して遊離 Glu 量が高く なっており, Gln から Gluへの変換が効率よく起こっ ていることが推察された。一方，小麦たんぱく配合酱

Taste and Color of Soy Sauce Supplemented with Wheat Gluten Takashi OKada (Research Laboratory, Higashimaru Shoyu Co. Ltd.) Harumi Katsura (Research Laboratory, Higashimaru Shoyu Co. Ltd.) Makio KoBAYASHI (Research Laboratory, Higashimaru Shoyu Co. Ltd.) 


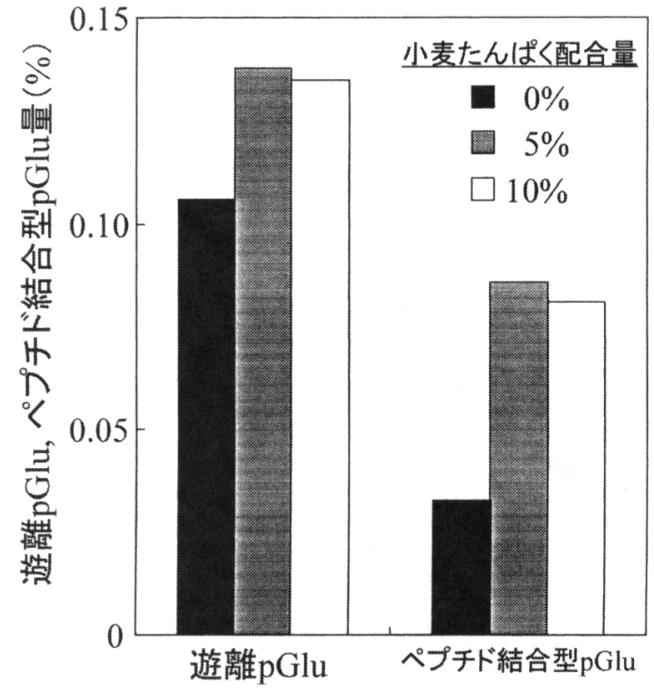

第 1 図 小麦たんぱく配合酱油の遊離 pGlu，ペプ チド結合型 $\mathrm{pGlu}$ 含量

油では扔抒むねぺプチド結合型 pGlu量が高くなって いたが，小麦たんぱくを5-10\%配合した時に，その 含有量が高まることがわかった（第 1 図）。また，遊 離 $\mathrm{pGlu}$ とペプチド結合型 $\mathrm{pGlu}$ を比較すると, 小麦 たんぱく無配合に比べて，5\%配合では遊離 pGluが 1.3 倍増加したのに対し，ペプチド結合型 pGlu は約 3 倍に増加していた（第1図）。したがって，滰油醸 造では遊離態よりもペプチド態においてピロ化が進み やすいことを示唆している。

続いて，小麦たんぱく配合酱油（0，5，10\%）を用 い,「関西風うどんだし」を調理して, 小麦たんぱく 無配合の酱油を対照とする二点識別試験法により, 官 能評価を行った ${ }^{6)}$ 。その結果，小麦たんぱくを $5 \%$ 配 合することで，有意に旨味と味の厚みを強く感じる傾 向が見られた。さらに小麦たんぱくを10\%配合する と, ダシ味, 旨味, まろやかさ, および総合評価の項 目で有意差が認められた。すなわち, 小麦たんぱくを 5-10\%配合した奨油では, 旨味が強く, ダシ味の効い たおいしい「関西風うどんだし」が調理できることが わかった。この要因として, 遊離 Glu量に加えて pGlu ペプチド量が高くなっているために, pGlu ペプ チドがGluの旨味を相乗的に増強することが考えら れた。したがって, 酱油の呈味性（おいしさ）に関与 する成分として, Glu と pGlu ペプチドの両方が重要 であることが示唆された。
第 1 表 低分子，高分子画分のペプチド結合型 pGlu 量と呈味効果

\begin{tabular}{cccc}
\hline \multirow{2}{*}{ 画分 } & \multirow{2}{*}{\begin{tabular}{c} 
ペチ゚゙結合型 \\
\cline { 3 - 4 }
\end{tabular}} & \multicolumn{2}{c}{ パネリストの数 } \\
\cline { 3 - 4 } & $\mathrm{p} G \mathrm{r}(\%)$ & 旨味 & 酸味 \\
\hline 低分子画分 & 1.667 & 18 & 6 \\
高分子画分 & 1.108 & 8 & 20 \\
二点識別試験 & - & $\mathrm{P}<0.05$ & $\mathrm{P}<0.01$ \\
\hline
\end{tabular}

小麦たんぱく麹の消化液から, 限外ろ過膜を用いて低 分子画分と高分子画分に分画した。それぞれの画分を 基本味液 (0.05\% MSG，0.05\%クエン酸）に添加して, 官能評価を行った。パネリストの数は, 味を強く感じた 人数を示す。

pGlu ペプチドの呈味効果をより詳しく検証するた め，小麦たんぱく敖の消化液から限外万過膜を用いて pGluペプチドの分子量分画物を調製した。分子量 1,000 以下の画分（低分子画分）でペプチド結合型 pGlu 量が高くなって扔り (第 1 表), この画分を基本 味液 $(0.05 \% \mathrm{MSG} ， 0.05 \%$ クン酸) に添加して官 能評価を行うと, 分子量 10,000 以上の画分（高分子 画分）と比較して, 旨味を強く, 酸味を弱く感じる傾 向が認められた。それゆえ, 小麦たんぱく辚の消化液 に含まれる低分子画分の中には, 旨味を増強し, 酸味 を抑制するぺプチドが存在する可能性が高いと考えら れた。酸味が弱いほど, ダシ風味を強く感じることが 経験的に知られており,「関西風うどんだし」の官能 評価で，小麦たんぱく配合奨油（10\%）においてダシ 味に有意差が認められたこととも相関する。Schlichtherle-Cerny ら ${ }^{4)}$ は, グルテンの酵素分解物から 4 種類の pGlu ペプチド（pGlu-Pro-Ser, pGlu-Pro, pGlu-Pro-Glu, pGlu-Pro-Gln）を同定し,これらの 呈味増強効果を報告している。今回, HPLCでの分 析結果を示さなかったが, 低分子画分から pGlu-Pro -Glu, pGlu-Pro-Gln と一致するピークが検出された。 また,これらの pGlu ペプチドは小麦たんぱく配合量 と正の相関が見られた。

\section{3. 酱油の褐変}

醸造中の奨油色度の推移を第 2 図 $\mathrm{A}$ に示すが, 小 麦たんぱく配合量が多いほど, 総窒素あたりの色度 $\left(\mathrm{OD}_{530} / \mathrm{T} . \mathrm{N}\right.$ 值) が終始低く推移した。また, 第 2

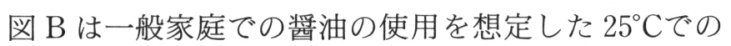


A

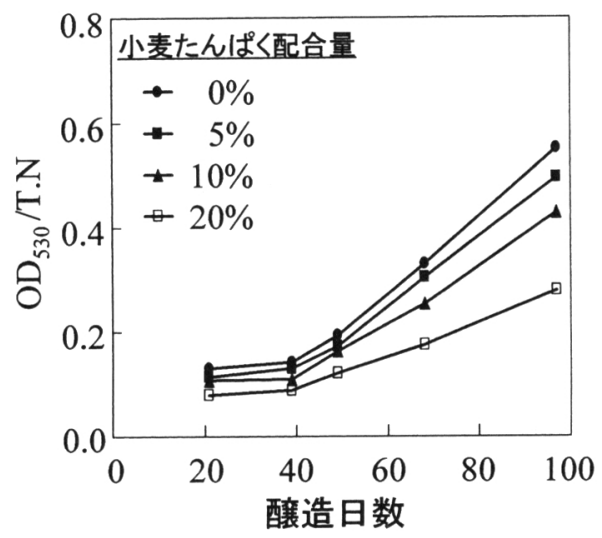

B

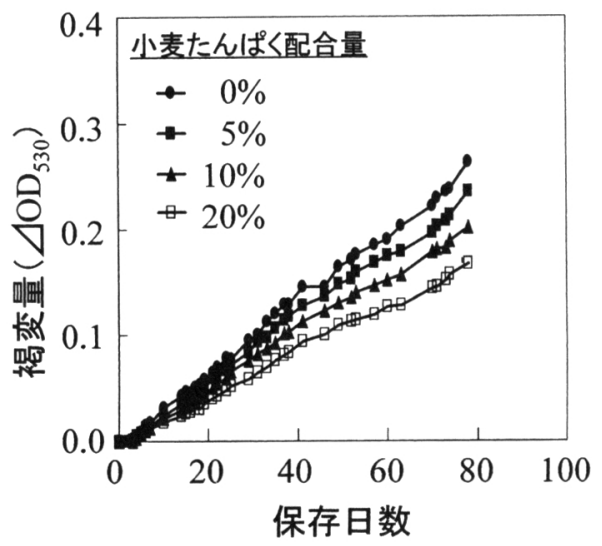

第 2 図釀造中（A）及び火入れ後（B）の褐変

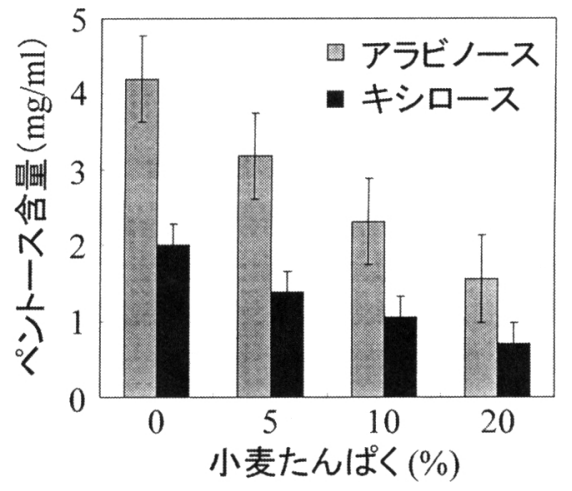

第 3 図 小麦たんぱく配合輏油のペントース含量

総窒素を 1.2 亿調整した酱油のペントース含 量を測定した。

抜き取り試験に扔ける酸化蝎変の結果を示しているが, 同様に小麦たんぱく配合量が多いほど, 褐変量 ( $\mathrm{OD}_{530}$ の増加量) が抑制された。従って, 小麦たん ぱく配合による褐変抑制効果が醸造中のみならず，火 入れ工程を経て容器に充填された後でも維持されるこ とが示された。

褐変が抑制された要因として, 小麦たんぱくには褐 変反応に寄与するペントース（キシロース，アラビ） 一ス）の含有量が低くなっていることが挙げられ ${ }^{1,10)}$, 小麦たんぱく配合量が多いほど，総窒素あたりのペン トースの含有量が少なくなっていた（第 3 図）。さら に， $\mathrm{N}$ 末端側がピロ化された $\mathrm{pGlu}$ ペプチドはアミノ カルボニル反応が起こりにくいことが予想されたので,

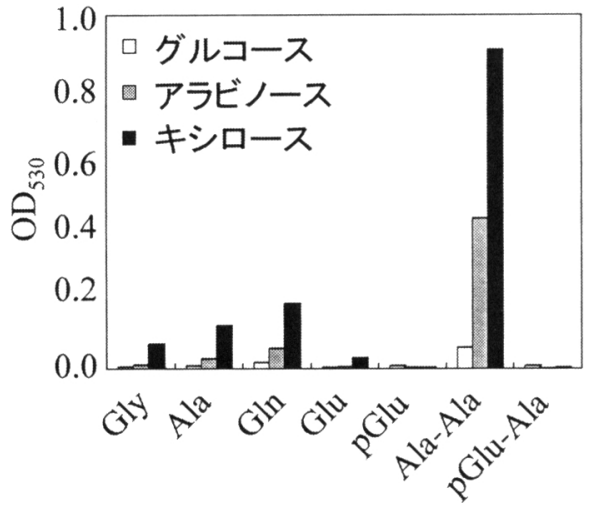

第 4 図 pGlu化されたアミノ酸,ペプチドのモデル褐 変試験

これらのモデル褐変を検討した (第 4 図)。遊離 $\mathrm{pGlu}$ をグルコースと反応させた場合, 他のアミノ酸の褐変 と大きな差は見られなかったが，アラビノース，キシ ロースと反応させた場合には，他のアミノ酸に比べて 遊離 pGluの褐変は低かった。ペプチドの場合, AlaAla と各糖質を反応させると, 遊離アミノ酸に比べて 大きな褐変が起こった。特に, アラビノース, キシロ 一スと反応させた場合に顕著であった。一方， $\mathrm{N}$ 末 端がピロ化された pGlu-Ala では，いずれの場合にも 褐変は進行しなかった。これらの結果は, 小麦たんぱ く配合奨油に含まれる pGluペプチドが, 酱油の味だ けではなく, 着色にも関与していることを示唆してい る。 
A

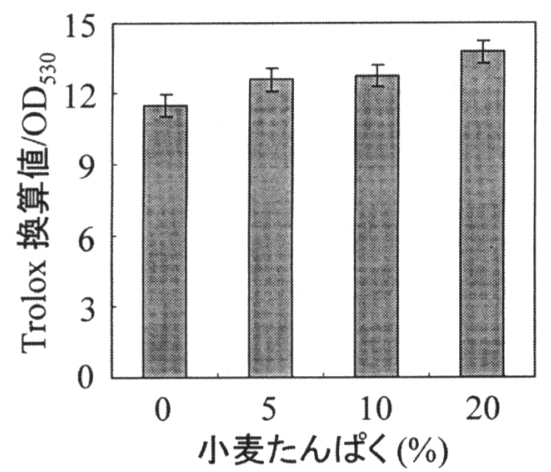

B

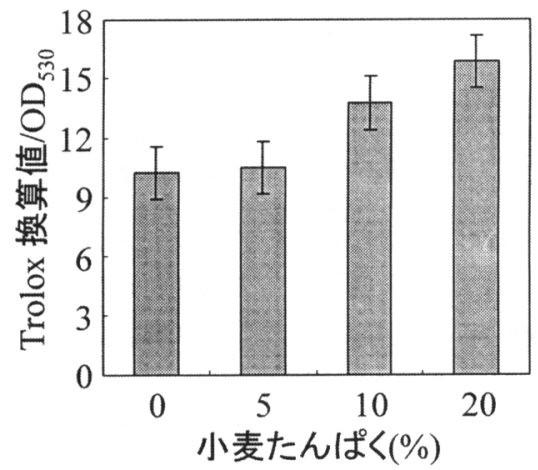

(B) の抗酸化力

\section{4. 䚈油の抗酸化力}

麹菌や酵母などの微生物（酵素）の働きによりつく られる醸造食品は, 総じて高い抗酸化力をもつことが 明らかにされている。例えば，これまでに醸造食品の 抗酸化性について, 輏油 ${ }^{11,12)}$ をはじめ, 味噌 ${ }^{13-15)}$, 清酒 ${ }^{16)}$, みり (17), ビール $^{18)}$ などで研究が報告され ている。これらに含まれる抗酸化物質は, 原料そのも のに由来するものだけではなく, 醸造中に微生物の作 用によって生成されるものも多くあり, 抗酸化物質の 種類は多岐にわたる。抗酸化物質は, 䤑造食品の保存 性を高めることはもちろん, 醇造過程における酸化ス トレスを抑制し, 味や香りなどの品質劣化を防止して いると考えられる。篠塚ら ${ }^{18)}$ は, ビールの劣化で最 も重要な問題である香味の老化を防止するため, 原料 由来のポリフェノールなど抗酸化物質の消費を抑制す ることで，ビールの香味耐性を向上させるとともに， 醸造中の抗酸化力の推移が劣化の指標となることを示 している。

奨油の抗酸化力と酸化褐変の関係を明らかにするた めに, 小麦たんぱく配合奨油について DPPH ラジカ ル消去能を測定したところ, 生揚奨油, 及び火入れ酱 油のいずれにおいても，小麦たんぱく配合量が多くな るにつれて抗酸化力が高くなることが確認できた（第 5 図)。㜔油の抗酸化力については, 色の濃い輏油, つまり褐変物質であるとともに抗酸化物質でもあるメ ラノイジンの含有量の高い酱油で抗酸化力が高いとす る報告がある一方で'11，メラノイジン以外の抗酸化物
質による奨油の抗酸化力への寄与が大きいことも示さ れている12)。それゆえ，小麦たんぱく配合量が多い輏 油において抗酸化力が高いことの要因として，小麦た んぱく（グルテン）に由来する抗酸化ペプチドの存在 が考えられ，醤油の酸化褐変抑制に寄与している可能 性が示唆された。

そこで, 小麦たんぱく分解物の抗酸化ペプチドとし て，小麦たんぱく敖の消化液からラジカル消去能の高 いペプチド分画物を調製し，奨油に 1\%（w/v）添加 したところ， $30^{\circ} \mathrm{C} て ゙ 7$ 日目の酸化褐変を $11 \%$ 抑制す ることができた。滰油に含まれる抗酸化物質として, メラノイジン, 原料由来のポリフェノール類, 原料た んぱくが趋菌酵素に分解されて生成するアミノ酸, ぺ プチド, 趜菌や酵母などの代謝物などが挙げられるが, これらの存在比は奨油醸造の各段階で異なる。特に, 諸味は酵母の増殖や混合のために通気攪汼されるため, 活性酸素に起因するフリーラジカル反応が褐変の進行 に大きく関わっていると考えられる。したがって，小 麦たんぱく由来の分解ペプチドがこれらのラジカルを 消去して滰油の褐変抑制に寄与することが示唆される と同時に，抗酸化力測定が奨油の褐変をモニターする 上で重要な指標の一つとなる可能性も示された。

\section{5. 酱油の金属キレート作用}

$\mathrm{Fe}, \mathrm{Cu}$ などの遷移金属は活性酸素の発生に関与す るため，金属キレート作用も広義の抗酸化力の一つと 考えることができる。また，酱油中には約 $30 \mathrm{ppm} の$ 鉄分が含まれ，濃化褐変反応を促進する要因の一つと 


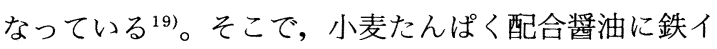
オンを添加した時の酸化褐変を調べたところ，小麦た んぱく無配合の酱油では鉄イオン添加量が多くなるに つれて褐変が促進され，60 ppm の添加で 7 日後の褐 変が $32 \%$ 促進された（第 6 図）。一方，小麦たんぱく を $20 \%$ 配合した眢油では鉄イオンの褐変促進効果は ほとんど認められなかったことから，小麦たんぱく由 来の分解ペプチドによる金属キレート作用の効果が示 唆された。小麦分解ペプチドには $\mathrm{G} \ln$ が構成アミノ

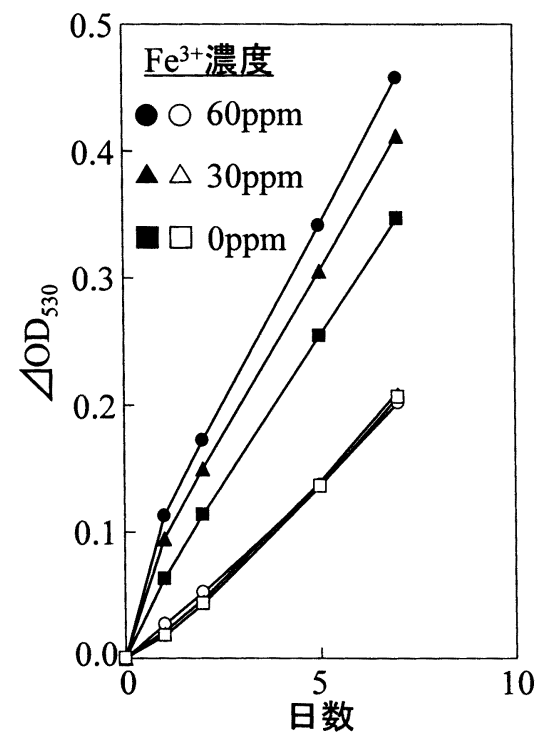

第 6 図 鉄イオン存在下での褐変 小麦たんぱく：0\%（○)，20\%（○）
酸の中心を担っており，この構造的特徵は金属キレー 卜作用の存在を支持している。すなわち, Gln の側鎖 にはアミン基が存在し, その窒素の孤立電子対が電子 供与性をもつためにキレートの安定化に寄与すると考 えられる ${ }^{20)}$ 。今回は生揚酱油の結果のみを示したが, 火入れ奨油でも同様の結果が得られたので, 醇造中の みならず製品酱油においても，金属キレート作用が持 続するものと期待される。

\section{6. おわりに}

本研究をまとめて酱油醸造における小麦たんぱく （グルテン）の分解フローを第 7 図に示した。酱油醸 造では, Gln は敖菌酵素のグルタミナーゼにより旨味 成分である Gluに変換される。これまでの研究では, 化学的に変換されて生成する遊離 pGlu 量を抑制して 遊離 Glu を高めることが重要とされてきた ${ }^{211} 。 一$ 一方, 奨油醸造におけるぺプチドのピロ化については全く研 究が行われていなかった。我々は, 㖶油醸造における ペプチドのピロ化を初めて明らかにするとともに，酱 油に存在する pGlu ペプチドの意義として, 呈味増強 効果と褐変反応抑制について示すことができた。その 他に小麦たんぱく配合滰油の淡色化効果の要因として, (1)ペントース含量が低いこと，(2)ラジカル消去能を有 するペプチドが生成すること，(3)金属キレート作用の あるぺプチドが生成すること，の 3 つが考えられた。 これらの抗酸化ぺプチドがピロ化しているかは不明で あるが, 今後, これらの抗酸化ぺプチドの精製を行い, 奨油中におけるペプチドのピロ化の効果を検討する予

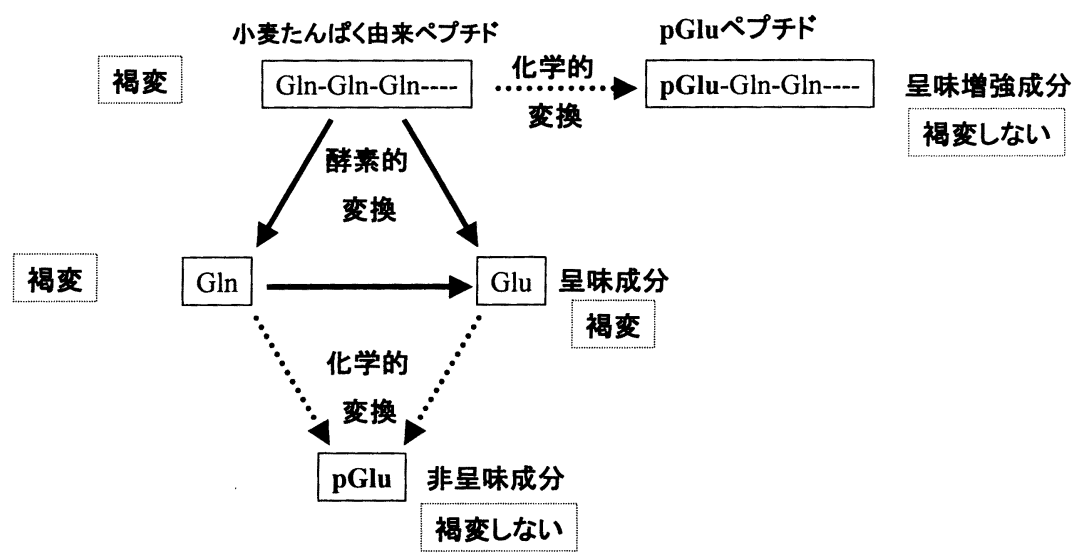

第 7 図 酱油醇造における小麦たんぱく（グルテン）の分解フロー 
定である。

酱油の品質を決定する三大要因は, 色, 味, 香であ るが, 特に淡口酱油は色が淡いことで料理素材の色を 鮮やかに仕上げるとともに，滰油味を前面に出さず， 素材の持ち味やダシ味を活かすことを特徴としている。 小麦たんぱくを副原料に使用することにより, pGlu ペプチドなどの機能性成分が, 淡口酱油の色や味の持 ち味をより一層高めることに寄与するものと考えられ る。

<ヒガシマル酱油(㑣 $>$

\section{参考文献}

1）遠藤 繁: 小麦の科学 (長尾精一編), p. 83105, 朝倉書店, 東京 (1995).

2) Suetsuna, K. and Chen, J.-R.: Food Sci. Technol. Res., 8, 227-230 (2002).

3）鈴木良雄：食品と開発，35(8)，44-46（2000）.

4) Schlichtherle-Cerny, H. and Amado, R. : J. Agric. Food Chem., 50, 1515-1522 (2002).

5）岡田 崇, 桂 晴美, 古林万木夫: 生物工学, 82 (11), 514-518 (2004).

6) 桂 晴美, 岡田 崇, 古林万木夫: 生物工学, 83 (1), 2-6 (2005).

7) Sato, K., Nishimura, R., Suzuki, Y., Motoi, H., Nakamura, Y., Ohtsuki, K., and Kawabata, M.: J. Agric. Food Chem., 46, 3403-3405 (1998).

8) Suzuki, Y., Motoi, H., and Sato, K. : J. Agric.
Food Chem., 47, 3248-3251 (1999).

9) Higaki-Sato, N., Sato, K., Esumi, Y., Okumura, T., Yoshikawa, H., Tanaka-Kuwajima, C., Kurata, A., Kotaru, M., Kawabata, M., Nakamura, Y., and Ohtsuki, K. : J. Agric. Food Chem., 51, 8-13 (2003).

10）中田佳幸, 森下めぐみ, 橋本忠明, 辻 安信 : 醸協, 94, 346-351 (1999).

11) Long, L. H., Kwee, D. C. T. and Halliwell, B. : Free Radic. Res., 32, 181-186 (2000).

12) Ando, M., Harada, K., Kitao, S., Kobayashi, M. and Tamura, Y. : Int. J. Mol. Med., 12, 923 -928 (2003).

13）江崎秀男, 川岸舜朗: 醸協, 97, 3945 (2002).

14）松田茂樹, 工藤康文：醸協，96，100106 (2001)

15）山口直彦：醸協，87，721-725（1992）

16）太田剛雄, 高下秀春, 轟木康市, 岩野君夫, 大 場俊輝：醸協，87，922-926（1992）.

17）石崎俊行, 高倉 裕, 吉浜義雄, 平松順一, 高 橋康次郎, 猪飼勝重：醸協, 98,861868 (2003).

18）篠塚 健, 高塩仁愛, 金田弘挙, 山岸信久：農 化, 74, 967-973 (2000).

19）橋場弘長, 越山育則, 坂口健二, 井口信義：農 化, 44，312-316（1970).

20）池 成圭: FOOD Style 21, 6, 90-92（2002）.

21）門脇 清：増補 奨油の科学と技術（栃倉辰六 郎編), p. 121-151, 日本醸造協会, 東京 (1994).

\section{執筆者紹介（順不同・敬称略）}

\section{岡田 崇 $<$ Takashi OKADA>}

昭和 49 年 3 月 8 日生れ<勤務先とその所在地 $>$ 七 ガシマル醬油株式会社研究所 $<$ 略歷 $>$ 平成 8 年京都大 学農学部農芸化学科卒業, 平成 10 年京都大学大学院農 学研究科修士課程応用生命化学専攻修了, 平成 10 年七 ガシマル醬油株式会社研究所, 現在に至る。<抱負 > 醬 油の抗酸化力を高める方法を追求し, 褐変や劣化の起 こりにくい醬油を醸造できるようにしたい。く趣味> 旅行, ドライブ
柴田和憲 $<$ Kazunori SHIBATA $>$

昭和 31 年 5 月 3 日生れ<勤務先とその所在地>ア サヒビール（株）商品技術開発本部 酒類研究所, $\bar{\top}$ 302-0106 茨城県守谷市緑 1-1-21<略歷>昭和 54 年 名古屋大学農学部農芸化学科卒, ビール工場醸造部, 酒類研究所, 新商品開発部等を経た後, 平成 17 年 1 月 酒類研究所長 現在に至るく抱負 $>$ 世界中で美味しい と評価されるお酒（ビール）つくりく趣味>ハイキン グ，クロスカントリースキー（なかなか機会なし）

古林万木夫 $<$ Makio KOBAYASHI >

第 100 巻, 第 2 号, P.101 参照 